\title{
Gonadal function in Hodgkin's disease: long-term follow-up of chemotherapy
}

\author{
J H X WAXMAN, Y A TERRY, P F M WRIGLEY, J S MALPAS, L H REES, G M BESSER, \\ T A LISTER
}

\begin{abstract}
A long-term study of gonadal function was conducted in 46 men and 28 women in prolonged remission of advanced Hodgkin's disease after cyclical combination chemotherapy with nitrogen mustard, vinblastine, prednisolone, and procarbazine. The mean follow-up was 6.9 years. Azoospermia or profound oligospermia occurred in 36 of the men, but late recovery was occasionally observed. Testosterone secretion was preserved. Amenorrhoea and gonadal hormone deficiency developed in 22 of the women and never recovered.

Partial or complete chemical sterilisation and gonadal hormone deficiency is currently a consequence of cure of advanced Hodgkin's disease in most patients.
\end{abstract}

\section{Introduction}

The observation that gonadal damage may occur in patients treated with cytotoxic drugs was first made in 1956. " Conventional" cyclical combination chemotherapy for Hodgkin's disease has an immediate effect on spermatogenesis. ${ }^{2} \mathrm{~A}$ similar though less dramatic effect on menstruation is seen, and the incidence of amenorrhoea correlates with the age of the patient at the time of treatment. ${ }^{3}$ We report on the long-term consequences for gonadal function of this curative combination chemotherapy. We undertook this follow-up study to determine whether spermatogenesis recovered or menses returned several years after the completion of treatment.

\section{Patients and methods}

Patients-We studied 46 men and 28 women in whom complete remission of advanced Hodgkin's disease had been achieved between 1968 and 1978 and who had not relapsed by 1981 (table I). All women had been premenopausal at the time of treatment.

Treatment-Cyclical combination chemotherapy with nitrogen mustard, vinblastine, prednisolone, and procarbazine (MVPP) was given for either six or 16 cycles. $^{4}$

Assessment of gonadal function-Seminal analysis was performed after a minimum of three days' abstinence. Menstruating women were studied on days 3-5 of their cycle. After basal blood specimens had been obtained for estimation of concentrations of prolactin (mean of three measurements), sex-hormone-binding globulin, testosterone, and $17 \beta$-oestradiol a standard test was performed in which luteinisinghormone-releasing hormone $(100 \mu \mathrm{g})$ was given. Concentrations of

ICRF Department of Medical Oncology, St Bartholomew's Hospital, London EC1A 7BE

J H X WAXMAN, BSC, MRCP, honorary senior registrar

Y A TERRY, SRN, sociologist

P F M WRIGLEY, PHD, FRCP, consultant physician

J S MALPAS, DPHIL, FRCP, professor

T A LISTER, MD, FRCP, senior lecturer

Department of Chemical Endocrinology, St Bartholomew's Hospital LESLEY H REES, MD, FRCP, professor

Department of Endocrinology, St Bartholomew's Hospital

G M BESSER, MD, FRCP, professor progesterone, if present, were measured on days 20-22 of a cycle. Follicle-stimulating hormone, luteinising hormone, and prolactin concentrations were measured by specific double antibody radioimmunoassay using MRC standards 69/104, 68/40, and $71 / 222$ respectively. After ether extraction testosterone and oestradiol con-

TABLE I-Patient details

\begin{tabular}{lccc}
\hline & $\begin{array}{c}\text { Age (mean) at } \\
\text { treatment } \\
\text { (years) }\end{array}$ & $\begin{array}{c}\text { Age (mean) at } \\
\text { follow-up } \\
\text { (years) }\end{array}$ & $\begin{array}{c}\text { Years (mean) after } \\
\text { chemotherapy }\end{array}$ \\
\hline Men & $12-55(27)$ & $16-61(34)$ & $2-12 \cdot 5(6 \cdot 5)$ \\
Women & $17-48(30)$ & $25-60(39)$ & $2-12 \cdot 5(7 \cdot 2)$ \\
\hline
\end{tabular}

centrations were measured by tritiated radioimmunoassay. Progesterone concentration was measured by tritiated immunoassay after hexane extraction. Concentrations of sex-hormone-binding globulin were measured by saturation radioimmunoassay. ${ }^{5}$

\section{Results}

MEN

Seminal analysis-Forty-one men produced serial samples of semen over periods of two to 12.5 years after chemotherapy. Profound oligospermia was noted in 36 men, with total counts between 0 and 0.66 million. The remaining five men had total counts between 20 and 88.4 million. Three patients who initially had azoospermia, and one with a count of 10 million, showed recovery to between 20 and 88.4 million over two to 10 years after the end of chemotherapy; they had all been aged between 20 and 30 years when treatment was started, and one fathered a normal child.

Hormone concentrations (table II)-Concentrations of testosterone and sex-hormone-binding globulin were normal in all patients. Three patients had marginally raised concentrations of $17 \beta$-oestradiol; 34 raised basal concentrations of follicle-stimulating hormone and luteinising hormone; two raised basal concentrations of luteinisinghormone alone; and six raised basal concentrations of folliclestimulating hormone alone; four men had normal basal gonadotrophin concentrations despite azoospermia in three. All 37 men tested had excessive responses of follicle-stimulating hormone after administration of luteinising-hormone-releasing hormone, while 34 had excessive responses of luteinising hormone. Four of the five patients with $N$ evidence of recovery of spermatogenesis had raised gonadotrophin concentrations basally and after administration of luteinising-hormonereleasing hormone. Prolactin concentrations were normal in all but eight patients.

\section{WOMEN}

Menstruation-Twenty-two of the 28 women with regular menses $\mathscr{D}$ before chemotherapy became amenorrhoeic. There was no late return of menstruation if periods had failed to return within three months $\overline{0}$ after the completion of treatment. Five of the six patients whose $\overrightarrow{\mathbb{D}}$ menses remained normal had been aged under 30 at the time of $\frac{\mathcal{Q}}{\Phi}$ treatment, and two of these subsequently had normal pregnancies $\varrho$ and delivered normal children. The correlation between age at the time of chemotherapy and subsequent menstrual state was close, with normal menses being retained in five out of 17 women aged under 30 at the time of chemotherapy (one out of three aged 10-19 and four out of 14 aged 20-29) compared with only one out of 11 aged 30 or over (one out of six aged 20-29 and none of five aged 40 or over). 
TABLE II-Hormone concentrations in 46 men and 28 women treated for Hodgkin's disease

\begin{tabular}{|c|c|c|c|c|c|c|}
\hline & \multicolumn{3}{|c|}{ Men. } & \multicolumn{3}{|c|}{ Women } \\
\hline & Range & Mean & Normal range & Range & Mean & Normal range \\
\hline Prolactin (mU/1) & $98-1114$ & 273 & $<360$ & $163-562$ & 289 & $<360$ \\
\hline Sex-hormone-binding globulin ( $\mathrm{nmol} / \mathrm{l})$ & $16-42$ & 27 & $17-50$ & $20->120$ & 56 & $38-102$ \\
\hline Testosterone $(\mathrm{nmol} / \mathrm{l})$ & $13-33$ & 21 & $10-38$ & $1-3 \cdot 2$ & 1.85 & $0 \cdot 5-3 \cdot 0$ \\
\hline $17 \beta$-Oestradiol $(\mathrm{pmol} / \mathrm{l})$ & $<30-205$ & 101 & $<30-128$ & $<30-525$ & 172 & $\left\{\begin{array}{c}110-1290 \text { premenopasal } \\
37-129 \text { postmenopausal }\end{array}\right.$ \\
\hline Progesterone (nmol/l) & & & & $<1-42 \cdot 4$ & $7 \cdot 33$ & $>33$ \\
\hline $\begin{array}{l}\text { Luteinising hormone }(\mathrm{U} / \mathrm{l}) \text { : } \\
\text { Baseline }\end{array}$ & $2 \cdot 9-28$ & 12 & $1 \cdot 4-9 \cdot 7$ & $2 \cdot 9->50$ & 29 & $2 \cdot 5-14 \cdot 1$ \\
\hline $\begin{array}{l}\text { Minutes after } 100 \mu \mathrm{g} \text { luteinising- } \\
\text { hormone-releasing hormone: } \\
20 \\
60\end{array}$ & $\begin{array}{r}34->50 \\
29 \cdot 8->50\end{array}$ & $\begin{array}{l}48 \\
37\end{array}$ & $\begin{array}{r}13 \cdot 1-57 \cdot 6 \\
11-47 \cdot 6\end{array}$ & $\begin{array}{l}33->50 \\
46->50\end{array}$ & $\begin{array}{l}48 \\
49\end{array}$ & $\begin{array}{l}15-42 \\
12-35\end{array}$ \\
\hline $\begin{array}{l}\text { Follicle-stimulating hormone (U/1): } \\
\text { Baseline }\end{array}$ & $3 \cdot 7->25$ & 15 & $1-7$ & $1 \cdot 5->25$ & 18 & $1-10$ \\
\hline $\begin{array}{l}\text { Minutes after } 100 \mu \mathrm{g} \text { luteinising- } \\
\text { hormone-releasing hormone: } \\
20 \\
60\end{array}$ & $\begin{array}{l}6 \cdot 6->25 \\
7 \cdot 6->25\end{array}$ & $\begin{array}{l}23 \\
24\end{array}$ & $\begin{array}{c}1-7 \\
0 \cdot 8-5 \cdot 2\end{array}$ & $\begin{array}{l}10 \cdot 7->25 \\
11 \cdot 7->25\end{array}$ & $\begin{array}{l}23 \\
23\end{array}$ & $\begin{array}{l}1 \cdot 2-11 \cdot 1 \\
1 \cdot 2-24 \cdot 5\end{array}$ \\
\hline
\end{tabular}

Conversion: SI to traditional units-Sex-hormone-binding globulin: $1 \mathrm{nmol} / 1 \approx 5 \cdot 2 \mu \mathrm{g} / 100 \mathrm{ml}$. Testosterone: $1 \mathrm{nmol} / 1 \approx 28 \cdot 8 \mathrm{ng} / 100 \mathrm{ml}$. $17 \beta-\mathrm{O}$ estradiol $: 1 \mathrm{pmol} / 1 \approx 26 \cdot 5$ $\mathrm{pg} / 100 \mathrm{ml}$. Progesterone: $1 \mathrm{nmol} / 1 \approx 31 \cdot 4 \mathrm{ng} / 100 \mathrm{ml}$.

Hormone concentrations (table II)-Gonadotrophin concentrations corresponded to menstrual state: in the women with amenorrhoea both high basal concentrations and an exaggerated response to administration of luteinising-hormone-releasing hormone were seen. As would be expected with ovarian failure, both oestradiol and progesterone concentrations were low. Testosterone concentrations were normal in all patients. The concentration of sex-hormonebinding globulin was raised in two women. All but seven women had normal prolactin concentrations (table II).

\section{Discussion}

It is now possible to cure a high proportion of patients with advanced Hodgkin's disease ${ }^{4}$; partial or complete sterilisation, however, has to be accepted as a consequence of current chemotherapy. In this study $36(88 \%)$ of the 41 men became azoospermic or severely oligospermic (less than one million sperm per ejaculate). A small proportion of men who had been under 30 years old at the start of treatment $(20 \%)$ showed partial recovery, although this was delayed by up to 10 years. None of the men developed impaired testosterone secretion or impotence. Twenty-two $(79 \%)$ of the 28 women became prematurely amenorrhoeic and deficient in gonadal hormones. Amenorrhoea was found to be permanent if menstruation failed to return three months after the completion of chemotherapy: this contrasts with the finding of Horning et al. ${ }^{6}$ The hypogonadism appeared from the detailed hormonal assessment to result from primary gonadal failure. In men and women the incidence of hypogonadism increased with the age at the start of treatment.

In men storage of sperm might be thought to be a means of circumventing the sterilising effect of chemotherapy. This is precluded, however, by the surprisingly high incidence of oligospermia at presentation. ${ }^{7}$ In women oestrogen deficiency induced by treatment is associated with sterility, ${ }^{3}$ loss of libido, ${ }^{8}$ and premature osteoporosis. ${ }^{9}$ Oestrogen replacement and counselling may prevent the latter sequelae of a premature menopause.

At present chemotherapy with MVPP, or minor variants, represents the only proved way of curing young adults with advanced Hodgkin's disease, which is otherwise invariably fatal. Thus this regimen will most probably remain central to the treatment of the disease in the near future, although preliminary reports suggest that an alternative combination is equally effective with no sterilising properties, and further studies are being carried out. ${ }^{10}$

It has been suggested that continuous prophylactic administration of oestrogens before or during chemotherapy might protect the ovary. Chapman and Sutcliffe recently reported on a series of six patients from this hospital (not included above) who received oestrogen throughout chemotherapy and concluded, on the basis of retention of menses and results of ovarian biopsies in these patients, that protection had been afforded.11 Caution must, however, be exercised in this interpretation, since all the patients were aged 30 or younger, two subsequently developed a premature menopause, and one had "menopausal" gonadotrophin concentrations. Additionally, these findings conflict with those in another, larger series. ${ }^{12}$ In spite of these reservations the hypothesis that "switching off" the gonad during treatment might protect it from chemotherapy is attractive and presents the only immediately possible prospect of avoiding the chemical sterilisation that is currently inevitable for most cured patients.

We thank Mrs Jo Barton, Lisa White, and Chris Pitman, who patiently typed the manuscript; the staff of the day ward, the chemical endocrinology laboratory, and the Williamson laboratory at St Bartholomew's Hospital; Mr L Perry for the steroid assays; and the patients who took part in the study.

\section{References}

${ }^{1}$ Louis J, Limarzi J, Best WR. Treatment of chronic granulocytic leukaemia with Myleran. Arch Intern Med 1956;97:299-308.

2 Chapman RM, Sutcliffe SBJ, Rees LM, Edward CRW, Malpas JS. Cyclical combination chemotherapy and gonadal function. Retrospective study in men. Lancet 1979;i:285-9.

${ }^{3}$ Chapman RM, Sutcliffe SBJ, Malpas JS. Cytotoxic induced ovarian failure in women with Hodgkin's disease. I. Hormone function. $\mathcal{F} A M A$ 1979;242:1877-81.

4 Sutcliffe SBJ, Wrigley PFM, Peto J, et al. MVPP chemotherapy regimen for advanced Hodgkin's disease. $\mathrm{Br}$ Med f 1978;i:679-83.

${ }^{5}$ Fattah DI, Chard T. Method for measuring sex hormone binding globulin. Clin Chem 1981 ;27:1277-9.

${ }^{6}$ Horning SJ, Hoppe RT, Kaplan HJ, Rosenberg SA. Female reproductive potential after treatment for Hodgkin's disease. $N$ Engl f Med 1981; 304:1377-82.

' Chapman RM, Sutcliffe SB, Malpas JS. Male gonadal dysfunction in Hodgkin's disease. A prospective study. $\mathcal{F} A M A$ 1981;245:1323-8.

${ }^{8}$ Chapman RM, Sutcliffe SB, Malpas JS. Cytotoxic-induced ovarian failure in Hodgkin's disease. II. Effects on sexual function. $\mathcal{F} A M A$ $1979 ; 242: 1882-4$.

${ }^{9}$ Stevenson JC, Whitehead MI. Postmenopausal osteoporosis. Br Med $\mathcal{J}$ $1982 ; 285: 585-8$.

10 Bonnadona G. The Rosenthal lecture. Cancer Res (in press).

11 Chapman RM, Sutcliffe SB. Protection of ovarian function by oral contraceptives in women receiving chemotherapy for Hodgkin's disease. Blood 1981 ;58:849-51.

12 Whitehead E, Shalet SM, Blackedge G, Todd I, Crowther D, Beardwell GG. The effect of combination chemotherapy on ovarian function in women treated for Hodgkin's disease. Cancer (in press).

(Accepted 15 September 1982) 